ISSN 2073-4352

www.mdpi.com/journal/crystals

Article

\title{
Polyoxotungstate-Surfactant Layered Crystal toward Conductive Inorganic-Organic Hybrid
}

\section{Takeru Ito ${ }^{1, *}$, Nozomu Fujimoto ${ }^{1}$, Sayaka Uchida ${ }^{2,3}$, Jun Iijima ${ }^{4}$, Haruo Naruke ${ }^{4}$ and Noritaka Mizuno $^{2}$}

1 Department of Chemistry, School of Science, Tokai University, 4-1-1 Kitakaname, Hiratsuka 259-1292, Japan; E-Mail: fujinz1985@ gmail.com

2 Department of Applied Chemistry, School of Engineering, The University of Tokyo, 7-3-1 Hongo, Bunkyo-ku, Tokyo 113-8656, Japan; E-Mails: csayaka@mail.ecc.u-tokyo.ac.jp (S.U.); tmizuno@mail.ecc.u-tokyo.ac.jp (N.M.)

3 Department of Basic Science, Graduate School of Arts and Sciences, The University of Tokyo, 3-8-1 Komaba, Meguro-ku, Tokyo 153-8902, Japan

4 Chemical Resources Laboratory, Tokyo Institute of Technology, 4259-R1-23, Nagatsuta, Midori-ku, Yokohama 226-8503, Japan; E-Mails: jun-3.futsal@inm.res.titech.ac.jp (J.I.); hnaruke@gmail.com (H.N.)

* Author to whom correspondence should be addressed; E-Mail: takeito@keyaki.cc.u-tokai.ac.jp; Tel.: +81-463-58-1211 (ext. 3737); Fax: +81-463-50-2094.

Received: 12 February 2012; in revised form: 17 April 2012 / Accepted: 27 April 2012 / Published: 3 May 2012

Abstract: A polyoxotungstate-surfactant hybrid layered compound was synthesized as a single phase by using decatungstate $\left(\left[\mathrm{W}_{10} \mathrm{O}_{32}\right]^{4-}, \mathrm{W}_{10}\right)$ and hexadecylpyridinium $\left(\mathrm{C}_{16}\right.$ py). The X-ray structure analysis combined with infrared spectroscopy and elemental analysis revealed the formula to be $\left(\mathrm{C}_{16} \mathrm{py}\right)_{4}\left[\mathrm{~W}_{10} \mathrm{O}_{32}\right]\left(\mathrm{C}_{16} \mathrm{py}-\mathrm{W}_{10}\right)$. The layered structure consisted of alternative stacking of $\mathrm{W}_{10}$ inorganic monolayers and interdigitated $\mathrm{C}_{16}$ py bilayers with layered periodicity of $23.3 \AA$. Each $\mathrm{W}_{10}$ anion in the $\mathrm{W}_{10}$ inorganic monolayers was isolated by the hydrophilic heads of $\mathrm{C}_{16} \mathrm{py}$. The hybrid crystals of $\mathrm{C}_{16} \mathrm{py}-\mathrm{W}_{10}$ decomposed at around $500 \mathrm{~K}$. The conductivity of the hybrid layered crystal was estimated to be $4.8 \times 10^{-6} \mathrm{~S} \mathrm{~cm}^{-1}$ at $423 \mathrm{~K}$ by alternating current (AC) impedance spectroscopy.

Keywords: inorganic-organic hybrid; layered crystal; polyoxometalate; surfactant 


\section{Introduction}

Inorganic-organic hybrid layered compounds exhibit higher structural flexibility than purely inorganic compounds owing to their organic components [1-8]. The synergy of inorganic and organic character is beneficial for synthesizing functional materials. Conductive hybrid compounds composed of organic cations and inorganic anions have been reported, and the molecular structures and arrangements of components have been precisely controlled for the emergence of conductive functions [1-6].

Combination of polyoxometalates (POMs) and surfactant cations [9-11] leads to promising functional inorganic-organic layered hybrids. POMs can add various physicochemical properties to the hybrids as inorganic components [12-16], while surfactants enable the control of layered structures as structure-directing organic components [17-19]. While there are many types of POM-surfactant hybrid [9-11,20-25], POM-surfactant single crystals are rare [26-32]. These POM-surfactant hybrids can allow fine tuning of the structures and functions, and are promising conducting materials as precedented inorganic-organic hybrid conductors [2,3]. In addition, polyoxotungstate-surfactant hybrids are less reducible, and more structurally stable than those of polyoxomolybdates [12,16]. Among several polyoxotungstates, a decatungstate $\left(\mathrm{W}_{10} \mathrm{O}_{32}{ }^{4-}, \mathrm{W}_{10}\right)$ works as a characteristic electron acceptor [33-35]. The conductivity of the hybrid crystals is expected to be enhanced by the $\pi$-electrons of surfactants such as hexadecylpyridinium $\left(\left[\mathrm{C}_{5} \mathrm{H}_{5} \mathrm{~N}\left(\mathrm{C}_{16} \mathrm{H}_{33}\right)\right]^{+}, \mathrm{C}_{16}\right.$ py). However, there is no polyoxotungstate-surfactant hybrid analyzed by single crystal X-ray crystallography, while a few polyoxotungstate crystals containing a long methylene moiety ( $\sim 6$ methylene groups) have been reported [36-38].

Here we report the synthesis of a hybrid compound of $\mathrm{C}_{16} \mathrm{py}$ and $\mathrm{W}_{10}\left(\mathrm{C}_{16} \mathrm{py}-\mathrm{W}_{10}\right)$. The crystal structure was successfully determined by the X-ray structure analysis. The conductive property was also investigated.

\section{Results and Discussion}

\subsection{Crystal Structure of $C_{16} p y-W_{10}$}

IR spectra of as-prepared precipitates, recrystallized samples, and crystals prepared with $\mathrm{Na}-\mathrm{W}_{10}$ showed the presence of $\mathrm{C}_{16}$ py cations and $\mathrm{W}_{10}$ anions. The single crystal X-ray structure analysis combined with the elemental analysis revealed the formula of $\mathrm{C}_{16} \mathrm{py}-\mathrm{W}_{10}$ to be $\left[\mathrm{C}_{5} \mathrm{H}_{5} \mathrm{~N}\left(\mathrm{C}_{16} \mathrm{H}_{33}\right)\right]_{4}\left[\mathrm{~W}_{10} \mathrm{O}_{32}\right]$ (Table 1). Four $\mathrm{C}_{16}$ py cations (1+ charge) were associated with one $\mathrm{W}_{10}$ anion (4- charge), and $\mathrm{C}_{16} \mathrm{py}-\mathrm{W}_{10}$ did not contain any $\mathrm{H}^{+}$. Figure 1 shows the crystal structure of $\mathrm{C}_{16}$ py- $\mathrm{W}_{10}$. The crystal packing consisted of alternating $\mathrm{W}_{10}$ inorganic layers and $\mathrm{C}_{16}$ py organic layers with periodicity of $23.3 \AA$ (Figure 1 ). The $\mathrm{W}_{10}$ anions formed monolayers, while the hexadecyl chains of $\mathrm{C}_{16}$ py interdigitated to form a bilayer structure, which is a typical structure for most POM-surfactant hybrid crystals [26-32]. All $\mathrm{C}-\mathrm{C}$ bonds in the hexadecyl chains showed anti conformation except one $\mathrm{C}-\mathrm{C}$ bond (C7-C8). While both $\mathrm{C}_{16} \mathrm{py}-\mathrm{W}_{10}$ and $\mathrm{C}_{16} \mathrm{pyCl} \cdot \mathrm{H}_{2} \mathrm{O}$ [39] contained interdigitated bilayers of $\mathrm{C}_{16}$ py with the pyridine ring inserted into the hydrophilic layers, the packing of hydrophilic layers was different; the $\mathrm{W}_{10}$ monolayers for $\mathrm{C}_{16} \mathrm{py}-\mathrm{W}_{10}$ and the $\mathrm{Cl}^{-}-\mathrm{H}_{2} \mathrm{O}$ bilayers for $\mathrm{C}_{16} \mathrm{pyCl} \cdot \mathrm{H}_{2} \mathrm{O}$. 
Table 1. Crystallographic data for $\mathrm{C}_{16} \mathrm{py}-\mathrm{W}_{10}$.

\begin{tabular}{|c|c|}
\hline Chemical formula & $\mathrm{C}_{84} \mathrm{H}_{152} \mathrm{~N}_{4} \mathrm{~W}_{10} \mathrm{O}_{32}$ \\
\hline Formula weight & 3568.54 \\
\hline Crystal system & triclinic \\
\hline Space group & $P \overline{1}($ No.2) \\
\hline$a(\AA)$ & $10.7727(12)$ \\
\hline$b(\AA)$ & $11.3734(12)$ \\
\hline$c(\AA)$ & $23.982(3)$ \\
\hline$\alpha\left(^{\circ}\right)$ & $98.566(4)$ \\
\hline$\beta\left(^{\circ}\right)$ & $95.298(4)$ \\
\hline$\gamma\left({ }^{\circ}\right)$ & $116.168(4)$ \\
\hline$V\left(\AA^{3}\right)$ & $2566.1(5)$ \\
\hline$Z$ & 1 \\
\hline$\rho_{\text {calcd }}\left(\mathrm{g} \mathrm{cm}^{-3}\right)$ & 2.309 \\
\hline$T(\mathrm{~K})$ & $213(2)$ \\
\hline$\mu(\mathrm{Mo} \mathrm{K} \alpha)\left(\mathrm{mm}^{-1}\right)$ & 11.230 \\
\hline No. of reflections measured & 41418 \\
\hline No. of independent reflections & 11736 \\
\hline$R_{\text {int }}$ & 0.0635 \\
\hline No. of parameters & 587 \\
\hline$R_{1}(I>2 \sigma(I))$ & 0.0354 \\
\hline$w R_{2}$ (all data) & 0.0842 \\
\hline
\end{tabular}

Figure 1. Crystal structure of $\mathrm{C}_{16} \mathrm{py}-\mathrm{W}_{10}$. (a) Packing diagram along $b$ axis $\left(\mathrm{W}_{10}\right.$ in polyhedral representations); (b) Asymmetric unit together with atoms generated by the symmetry operation $(-x,-y,-z$,$) to complete \mathrm{W}_{10}$ anion. Displacement ellipsoids are drawn at the $30 \%$ probability level, and $\mathrm{H}$ atoms are omitted for clarity.

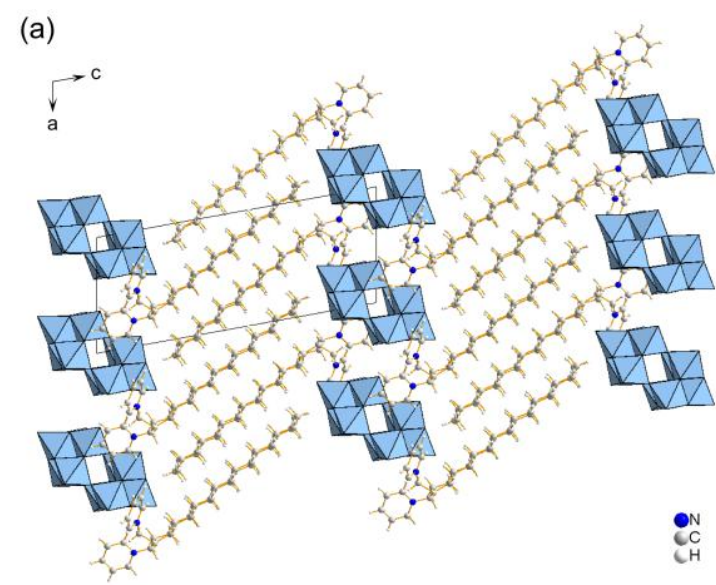

(b)

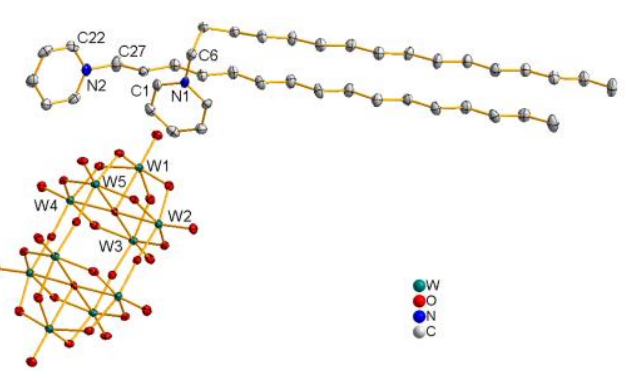


The hydrophilic heads of $\mathrm{C}_{16}$ py penetrated into the $\mathrm{W}_{10}$ inorganic monolayers and isolated each $\mathrm{W}_{10}$ anion (Figure 2 ) in a similar way to that in the crystal of $\mathrm{C}_{16}$ py-hexamolybdate $\left(\mathrm{C}_{16} \mathrm{py}-\mathrm{Mo}_{6}\right)$ [31] or $\mathrm{C}_{16} \mathrm{py}-\alpha$-octamolybdate $\left(\mathrm{C}_{16} \mathrm{py}-\alpha-\mathrm{Mo}_{8}\right)$ [32]. On the other hand, two independent $\mathrm{C}_{16} \mathrm{py}$ cations were not parallel (angle: $52.6^{\circ}$ ) without $\pi-\pi$ stacking, different from $\mathrm{C}_{16} \mathrm{py}-\mathrm{Mo}_{6}$ [31] and $\mathrm{C}_{16} \mathrm{py}-\alpha-\mathrm{Mo}_{8}$ [32]. The $\mathrm{C}-\mathrm{H} \cdots \pi$ (centroid) distance was $3.32 \AA$, and the nearest $\mathrm{C}-\mathrm{H}$ bond $(\mathrm{C} 24-\mathrm{H} 24)$ was not directed to the center of the pyridine ring. The shortest interatomic distance ( $\mathrm{C} 3 \cdots \mathrm{H} 24,2.88 \AA$ ) between the pyridine rings was almost the same as the sum of the van der Waals radii $(2.90 \AA)$. Therefore, $\mathrm{C}-\mathrm{H} \cdots \pi$ interaction $[40,41]$ was hardly observed in the present $\mathrm{C}_{16} \mathrm{py}-\mathrm{W}_{10}$.

Figure 2. Molecular arrangements in the inorganic layers of $\mathrm{C}_{16} \mathrm{py}-\mathrm{W}_{10}$. The hexadecyl groups are omitted for clarity.

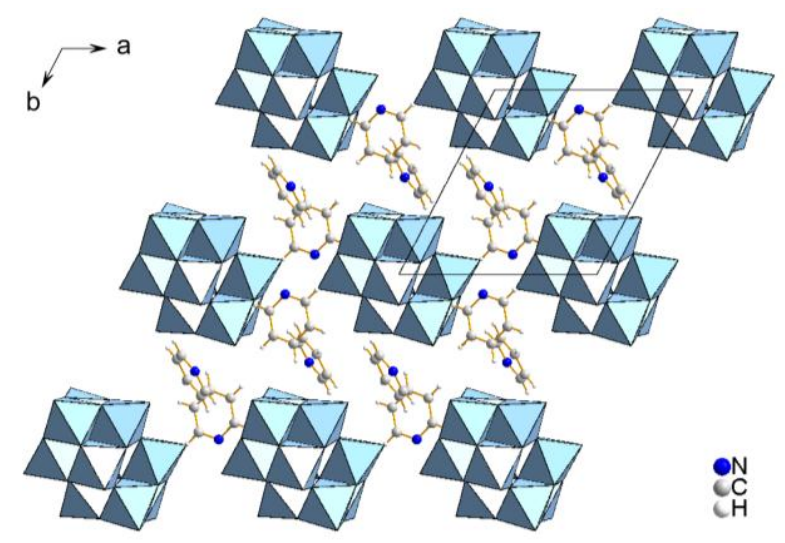

$\mathrm{C}_{16}$ py- $\mathrm{W}_{10}$ had two-dimensionally confined monolayers of the $\mathrm{W}_{10}$ anions (Figure 2). The distance between the nearest $\mathrm{W}_{10}$ anions was $3.23 \AA$, much shorter than that for $\mathrm{W}_{10}$ crystals composed of $n$-butyl- [42,43] or n-propylammonium [44] (5.4-5.8 $\AA$ ). The close distance between $\mathrm{W}_{10}$ would contribute to the emergence of conductivity for $\mathrm{C}_{16} \mathrm{py}-\mathrm{W}_{10}$.

$\mathrm{C}_{16}$ py- $\mathrm{W}_{10}$ had $\mathrm{C}-\mathrm{H} \cdots \mathrm{O}$ hydrogen bonds [40] at the interface between the $\mathrm{W}_{10}$ and $\mathrm{C}_{16}$ py layers. The C...O distances were 3.28-3.88 $\AA$ (Table 2). The mean value was $3.51 \AA$, and was shorter than the mean C $\cdots$ O distances $(\sim 3.6 \AA)$ in other POM hybrid crystals containing the $\mathrm{C}_{16}$ py cation [31,32]. These shorter hydrogen bonds as well as electrostatic interactions between $\mathrm{C}_{16}$ py and $\mathrm{W}_{10}$ would stabilize the layered crystal structure of $\mathrm{C}_{16} \mathrm{py}-\mathrm{W}_{10}$ with rigid packing. Most hydrogen bonds were formed between oxygen atoms of $\mathrm{W}_{10}$ and the hydrophilic head of $\mathrm{C}_{16}$ py (i.e., pyridine rings or methylene groups near nitrogen).

Table 2. $\mathrm{C}-\mathrm{H} \cdots \mathrm{O}$ hydrogen bonds in $\mathrm{C}_{16} \mathrm{py}-\mathrm{W}_{10}$.

\begin{tabular}{|c|c|c|c|}
\hline & 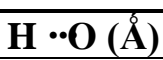 & C...O (Á) & C-H…O (deg) \\
\hline $\mathrm{C} 1{ }^{\mathrm{i}}-\mathrm{H} 1{ }^{\mathrm{i}} \cdots \mathrm{O} 15$ & $2.967(5)$ & $3.880(9)$ & $164.3(5)$ \\
\hline $\mathrm{C} 28^{\mathrm{i}}-\mathrm{H} 28 \mathrm{~B}^{\mathrm{i}} \cdots \mathrm{O} 8$ & $2.410(4)$ & $3.318(7)$ & $154.1(4)$ \\
\hline 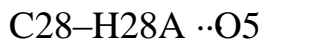 & $2.795(3)$ & $3.730(6)$ & $159.8(4)$ \\
\hline $\mathrm{C} 3-\mathrm{H} 3 \cdots \mathrm{O} 2$ & $2.634(4)$ & $3.550(8)$ & $164.7(5)$ \\
\hline $\mathrm{C} 21^{\mathrm{iii}}-\mathrm{H} 21 \mathrm{~A}^{\mathrm{iii}} \ldots \mathrm{O} 2$ & $2.476(4)$ & $3.380(11)$ & $155.2(5)$ \\
\hline $\mathrm{C} 26-\mathrm{H} 26 \cdots \mathrm{O} 4$ & $2.534(4)$ & $3.448(7)$ & $164.5(5)$ \\
\hline $\mathrm{C} 6{ }^{\mathrm{ii}}-\mathrm{H} 6 \mathrm{~A}^{\mathrm{ii}} \ldots \mathrm{O} 4$ & $2.384(5)$ & $3.278(9)$ & $151.3(4)$ \\
\hline
\end{tabular}

Symmetry codes: (i) $-1+x,-1+y, z$; (ii) $x,-1+y, z$; (iii) $-x, 2-y, 1-z$. 


\subsection{Powder X-Ray Diffraction (XRD) Patterns of $C_{16} p y-W_{10}$}

Powder XRD patterns of $\mathrm{C}_{16} \mathrm{py}-\mathrm{W}_{10}$ were measured at room temperature (Figure 3 ). The XRD pattern of as-prepared $\mathrm{C}_{16}$ py- $\mathrm{W}_{10}$ exhibited weak and broad peaks (Figure 3a). The XRD pattern of recrystallized $\mathrm{C}_{16} \mathrm{py}-\mathrm{W}_{10}$ showed much sharper and stronger peaks (Figure $3 \mathrm{~b}$ ), while the peak positions were close to those of the as-prepared $\mathrm{C}_{16} \mathrm{py}-\mathrm{W}_{10}$ (Figure 3a). This demonstrates that the structure of as-prepared $\mathrm{C}_{16} \mathrm{py}-\mathrm{W}_{10}$ is not changed by the recrystallization from hot acetonitrile. The pattern of the recrystallized $\mathrm{C}_{16} \mathrm{py}-\mathrm{W}_{10}$ (Figure $3 \mathrm{~b}, a=10.7588, b=11.5068, c=24.7480 \AA$, $\alpha=99.914, \beta=93.577, \gamma=116.664^{\circ}, V=2662.9 \AA^{3}$ [45]) was almost the same as that calculated with the single crystal $\mathrm{X}$-ray analysis data (Figure $3 \mathrm{c}$ ), indicating that the recrystallized $\mathrm{C}_{16} \mathrm{py}-\mathrm{W}_{10}$ is a single phase.

Figure 3. Powder $\mathrm{X}$-ray diffraction patterns of (a) as-prepared $\mathrm{C}_{16} \mathrm{py}-\mathrm{W}_{10}$ and (b) recrystallized $\mathrm{C}_{16} \mathrm{py}-\mathrm{W}_{10}$, and that (c) calculated with single crystal data.

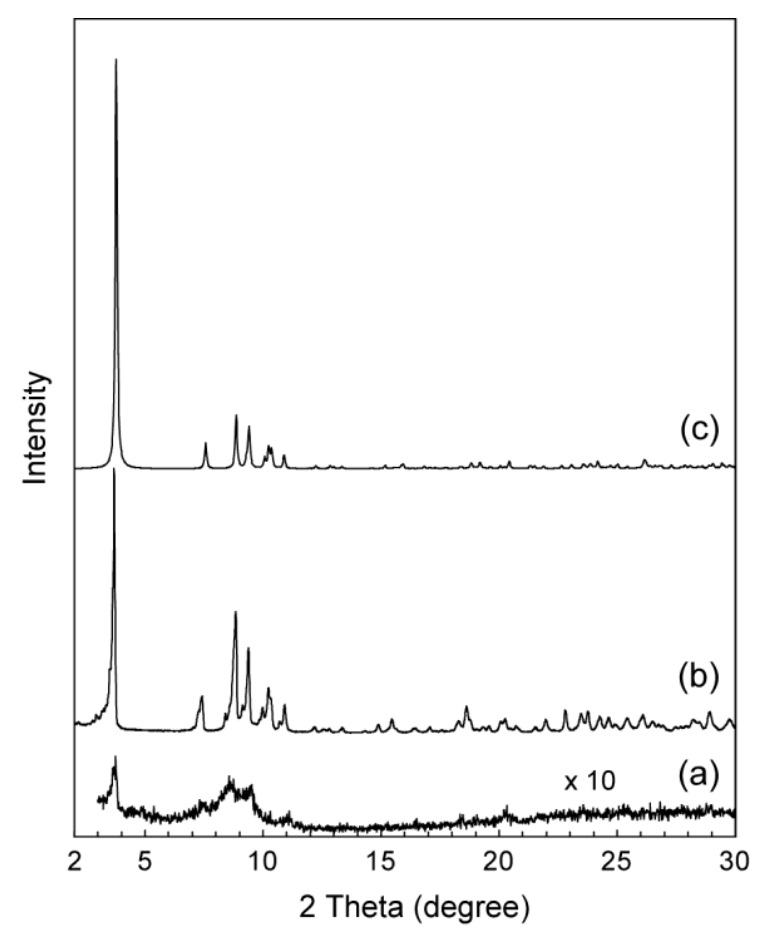

\subsection{Conductivity of $C_{16} p y-W_{10}$}

Figure 4 shows an impedance spectrum for the recrystallized $\mathrm{C}_{16} \mathrm{py}-\mathrm{W}_{10}$ at $423 \mathrm{~K}$. The spectrum showed a suppressed half circle in the high- and medium-frequency regions and an inclined line in the low-frequency region. The suppressed half circle consisted of two partially overlapped semicircles due to bulk and grain boundary resistances. The linear part in the low-frequency region would result from a combination of charge transfer resistance and Warburg impedance related to the diffusion of the carrier. The equivalent circuit [46-48] is shown in Figure 4: $R_{\mathrm{b}}$ and $C_{\mathrm{b}}$ are the resistance and capacitance of the bulk, respectively. $R_{\mathrm{gb}}$ and $C_{\mathrm{gb}}$ are the resistance and capacitance, respectively, of the grain boundary. $R_{\mathrm{ct}}$ and $C_{\mathrm{dl}}$ are the charge transfer resistance and double layer capacitance, respectively. $Z_{\mathrm{W}}$ is the Warburg impedance. The red line in Figure 4 represents fitted data with the equivalent circuit described above (Figure 4, inset), which successfully reproduces the measured impedance spectrum. 
The value of $R_{\mathrm{b}}$ obtained by the fitting was $2.25 \times 10^{4} \Omega$, from which the conductivity of the bulk $\mathrm{C}_{16} \mathrm{py}-\mathrm{W}_{10}$ was estimated to be $4.8 \times 10^{-6} \mathrm{~S} \mathrm{~cm}^{-1}$ considering uncertainty. The estimated value of $C_{\mathrm{b}}$ was $1.01 \times 10^{-6} \mathrm{~F}$, resulting in the time constant for the process in the bulk $\left(R_{\mathrm{b}} \times C_{\mathrm{b}}\right)$ of $2.27 \times 10^{-2} \mathrm{~s}$. This short time constant suggests that the bulk process occurs by electronic conduction [47], in good agreement with the fact that $\mathrm{C}_{16} \mathrm{py}-\mathrm{W}_{10}$ contains no easily moving ion such as $\mathrm{H}^{+}$. Figure 5 shows the thermogravimetric (TG) curve and IR spectra of recrystallized $\mathrm{C}_{16} \mathrm{py}-\mathrm{W}_{10}$. No weight loss was observed below $523 \mathrm{~K}$. The weight of $\mathrm{C}_{16} \mathrm{py}-\mathrm{W}_{10}$ decreased by $36 \%$ from $523 \mathrm{~K}$ to $723 \mathrm{~K}$ (Figure 5a), which was attributed to the decomposition and removal of the $\mathrm{C}_{16}$ py cations. The crystallinity of $\mathrm{C}_{16}$ py$\mathrm{W}_{10}$ revealed by powder XRD decreased after the impedance spectroscopy measurements (not shown). However, IR spectra before and after the measurements at $423 \mathrm{~K}$ (Figure $5 \mathrm{~b}$ ) exhibited characteristic peaks for the $\mathrm{W}_{10}$ anion in the range of $400-1000 \mathrm{~cm}^{-1}$ [49], demonstrating that the molecular structure of $\mathrm{W}_{10}$ was retained after heating at $423 \mathrm{~K}$. These results indicate that $\mathrm{C}_{16} \mathrm{py}-\mathrm{W}_{10}$ is thermally stable below $423 \mathrm{~K}$.

Figure 4. Nyquist spectrum (open circles) of recrystallized $\mathrm{C}_{16} \mathrm{py}-\mathrm{W}_{10}$ at $423 \mathrm{~K}$ and simulated spectrum (red line) based on an equivalent electronic circuit in the figure. The parameters obtained by the fitting (see text) are as follows: $R_{\mathrm{b}}=2.25 \times 10^{4} \Omega$, $C_{\mathrm{b}}=1.01 \times 10^{-6} \mathrm{~F}, R_{\mathrm{gb}}=6.55 \times 10^{4} \Omega, C_{\mathrm{gb}}=2.50 \times 10^{-6} \mathrm{~F}, R_{\mathrm{ct}}=3.50 \times 10^{4} \Omega$, $C_{\mathrm{dl}}=9.0 \times 10^{-4} \mathrm{~F}, \sigma=4.2 \times 10^{3} \Omega \mathrm{s}^{-1 / 2}\left(Z_{\mathrm{w}}=\frac{(1-j) \sigma}{\sqrt{\omega}}\right)$.

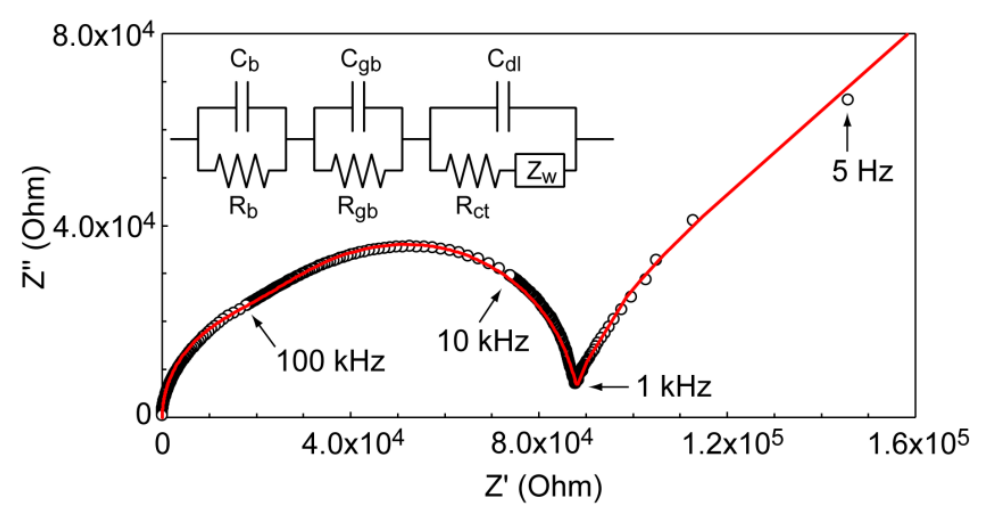

Figure 5. (a) $\mathrm{TG}$ curve of recrystallized $\mathrm{C}_{16} \mathrm{py}-\mathrm{W}_{10}$; (b) IR spectra of recrystallized $\mathrm{C}_{16} \mathrm{py}-\mathrm{W}_{10}$ before and after the impedance spectroscopy measurements at $423 \mathrm{~K}$.

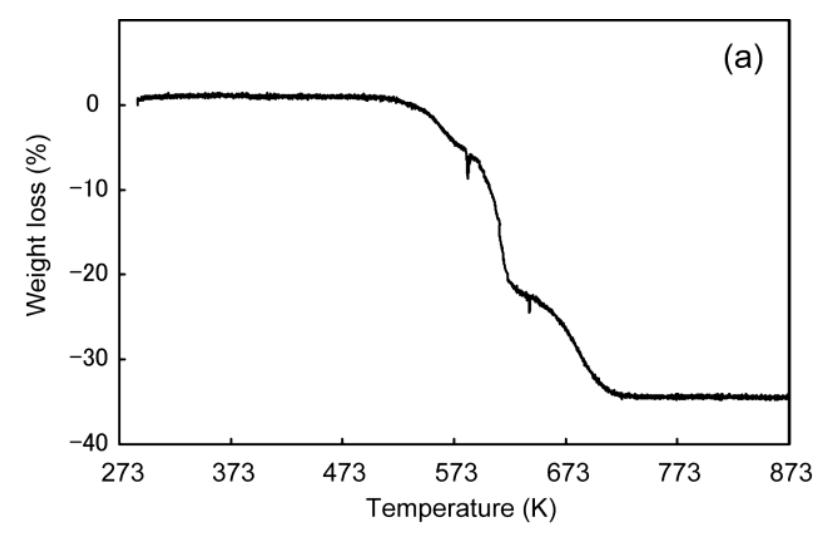


Figure 5. Cont.

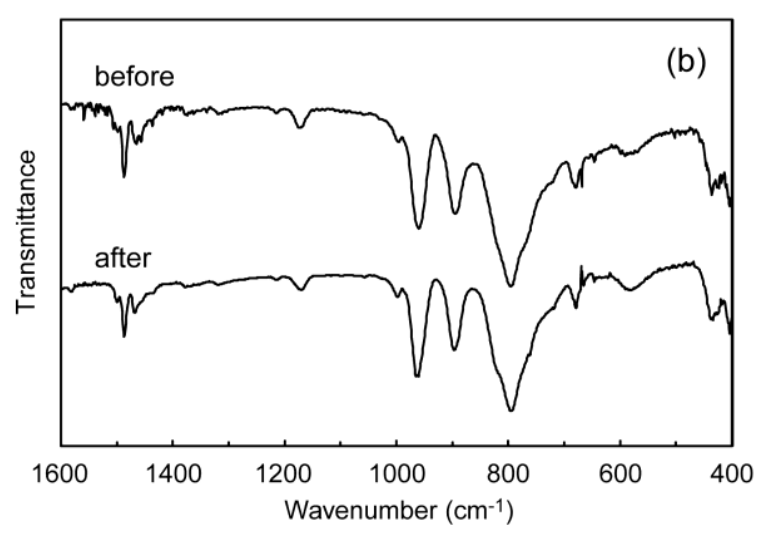

The conductivity of $\mathrm{C}_{16} \mathrm{py}-\mathrm{W}_{10}$ was much lower than the radical salts of POM containing organic donor such as bis(ethylenedithio)tetrathiafulvalene [2,3]. These radical salts have conductive layers of organic donor, which possibly leads to three-dimensional conduction. On the other hand, the conductivity of $\mathrm{C}_{16} \mathrm{py}-\mathrm{W}_{10}$ is considered to be two-dimensional along the inorganic layers composed of $\mathrm{W}_{10}$ and pyridinium hydrophilic heads ( $a b$ plane in the crystal). The anisotropy of the conductivity was difficult to investigate because large single crystals were not obtained. The conductivity of $\mathrm{C}_{16} \mathrm{py}-\mathrm{W}_{10}$ reported here was measured for pelletized ground powder, and is considered to be averaged and overall conductivity. Although the conductivity of $\mathrm{C}_{16} \mathrm{py}-\mathrm{W}_{10}$ was not so high, these results suggest that appropriate combination of POMs as electron reservoirs and surfactants with $\pi$-electrons would pave the way to another class of hybrid conductors.

\section{Experimental Section}

\subsection{Syntheses and Methods}

All chemical reagents were obtained from commercial sources. $\mathrm{C}_{16} \mathrm{py}-\mathrm{W}_{10}$ was synthesized according to a modified procedure of the preparation of tetrabutylammonium salt of $\mathrm{W}_{10}[49] .4 .0 \mathrm{~g}$ (12.1 mmol) of $\mathrm{Na}_{2} \mathrm{WO}_{4} \cdot 2 \mathrm{H}_{2} \mathrm{O}$ was dissolved in $25 \mathrm{~mL}$ of water, and then the solution was boiled and acidified with $8.4 \mathrm{~mL}$ of boiling $3 \mathrm{M} \mathrm{HCl}$ solution $(25 \mathrm{mmol})$ with vigorous stirring. After boiling for 2 min, $1.9 \mathrm{~g}(5.3 \mathrm{mmol})$ of $\left[\mathrm{C}_{5} \mathrm{H}_{5} \mathrm{~N}\left(\mathrm{C}_{16} \mathrm{H}_{33}\right)\right] \mathrm{Cl} \cdot \mathrm{H}_{2} \mathrm{O}\left(\mathrm{C}_{16} \mathrm{pyCl} \cdot \mathrm{H}_{2} \mathrm{O}\right)$ in water/ethanol $(20 \mathrm{~mL}, 1: 1(v / v))$ was added to form white precipitates followed by filtration and suction to dryness. Recrystallization of the crude product from hot acetonitrile gave colorless plates. The single crystals were obtained by drying up an acetonitrile solution of $\mathrm{C}_{16} \mathrm{py}-\mathrm{W}_{10}$, which was obtained by the cation exchange of sodium salt of $\mathrm{W}_{10}\left(\mathrm{Na}-\mathrm{W}_{10}\right)$ [34]. Data for $\mathrm{C}_{16} \mathrm{py}-\mathrm{W}_{10}$ (single crystals): Anal. Calcd for $\mathrm{C}_{84} \mathrm{H}_{152} \mathrm{~N}_{4} \mathrm{~W}_{10} \mathrm{O}_{32}$ : C, 28.3; H, 4.3; N, 1.6\%. Found: C, 28.4; H, 3.8; N, 1.6\%. IR (KBr disk): 952 (m), 917 (s), 859 (m), $806(\mathrm{~s}), 720(\mathrm{w}), 668(\mathrm{~m}), 554(\mathrm{w}) \mathrm{cm}^{-1}$.

IR spectra (as KBr pellet) were recorded on Jasco FT-IR 5000 and Horiba FT-710 spectrometers. Thermogravimetric and differential thermal analyses (TG-DTA) were performed on an ULVAC MTS9000 + TGD9600 system. Conductivity measurements were carried out by the alternating current (AC) impedance method in a frequency range from $5 \mathrm{~Hz}$ to $13 \mathrm{MHz}$ using an Agilent 4192A inductance-capacitance-resistance (LCR) meter. Pelletized powder samples of recrystallized 
$\mathrm{C}_{16} \mathrm{py}-\mathrm{W}_{10}(10 \mathrm{~mm}$ in diameter, $0.854 \mathrm{~mm}$ in thickness) were sandwiched with Pt electrodes, and the impedance was measured under a dry Ar atmosphere at $423 \mathrm{~K}$. Bulk resistances and conductivities of $\mathrm{C}_{16} \mathrm{py}-\mathrm{W}_{10}$ were estimated by the fitting of typical Nyquist plots.

\subsection{X-ray Diffraction Measurements}

Single crystal $\mathrm{X}$-ray diffraction measurements for $\mathrm{C}_{16}$ py- $\mathrm{W}_{10}$ were made on a Rigaku RAXIS RAPID imaging plate diffractometer with graphite monochromated Mo-K $\alpha$ radiation $(\lambda=0.71075 \AA$ ) . Diffraction data were collected for a platelet crystal $(0.30 \times 0.30 \times 0.02 \mathrm{~mm})$ and processed with PROCESS-AUTO [50]. The structure was solved by heavy-atom Patterson methods [51] and expanded using Fourier techniques [52]. The refinement procedure was performed by the full-matrix least-squares using SHELXL97 [53]. All calculations were performed using the CrystalStructure [54] software package. Numerical absorption correction was performed for the observed data. In the refinement procedure, all non-hydrogen atoms were refined anisotropically, and the hydrogen atoms on $\mathrm{C}$ atoms were located in calculated positions. Further details of the crystal structure investigation may be obtained free of charge from the Cambridge Crystallographic Data Centre, 12 Union Road, Cambridge CB2 1EZ, UK; Fax: +44-1223-336-033; or E-Mail: deposit@ccdc.cam.ac.uk (CCDC-865932).

Powder X-ray diffraction (XRD) patterns for $\mathrm{C}_{16}$ py- $\mathrm{W}_{10}$ were measured with a XRD-DSCII (Rigaku Corporation) diffractometer by using $\mathrm{Cu} K \alpha$ radiation $(\lambda=1.54056 \AA$, $50 \mathrm{kV}-300 \mathrm{~mA})$ at ambient temperature. A powder $\mathrm{C}_{16} \mathrm{py}-\mathrm{W}_{10}$ sample was sieved in a 200 mesh sieve to remove large particles and to avoid preferred orientation. Diffraction data were collected in the range of $2 \theta=2-30^{\circ}$ at $0.01^{\circ}$ point and $5 \mathrm{~s} /$ step. The lattice parameters were calculated using Materials Studio Softwares (Accelrys Inc.) by the peak profile fitting using the Pawley refinement [55].

\section{Conclusions}

Decatungstate-hexadecylpyridinium hybrid layered crystal, $\left[\mathrm{C}_{5} \mathrm{H}_{5} \mathrm{~N}\left(\mathrm{C}_{16} \mathrm{H}_{33}\right)\right]_{4}\left[\mathrm{~W}_{10} \mathrm{O}_{32}\right]$ $\left(\mathrm{C}_{16}\right.$ py- $\left.\mathrm{W}_{10}\right)$, was successfully synthesized by a simple cation-exchange reaction. $\mathrm{C}_{16} \mathrm{py}-\mathrm{W}_{10}$ was obtained as a single phase, and the crystal structure was determined by single crystal X-ray diffraction. $\mathrm{C}_{16}$ py- $\mathrm{W}_{10}$ contained the stacking of $\mathrm{W}_{10}$ monolayers and $\mathrm{C}_{16}$ py interdigitated bilayers. The alternating current (AC) impedance spectroscopy measurements revealed the conductivity of $\mathrm{C}_{16} \mathrm{py}-\mathrm{W}_{10}$ to be $4.8 \times 10^{-6} \mathrm{~S} \mathrm{~cm}^{-1}$ at $423 \mathrm{~K}$. Although the conductivity was considerably lower than the radical salts of POM [2,3] or other layered materials [5,6], $\mathrm{C}_{16} \mathrm{py}-\mathrm{W}_{10}$ shows the potential of polyoxometalate-surfactant hybrid crystals as conductive materials.

\section{Acknowledgments}

This work was supported in part by JSPS Grant-in-Aid for Scientific Research (No. 23750246), Nippon Sheet Glass Foundation, and Iketani Science and Technology Foundation. 


\section{References and Notes}

1. Batail, P. Molecular Conductors. In Chemical Reviews, Josef Michl Ed.; American Chemical Society: Washington, DC, USA, 2004; Volume 104, pp. 4887-5782.

2. Coronado, E.; Gómez-García, C.J. Polyoxometalate-based molecular materials. Chem. Rev. 1998, 98, 273-296.

3. Coronado, E.; Giménez-Saiz, C.; Gómez-García, C.J. Recent advances in polyoxometalatecontaining molecular conductors. Coord. Chem. Rev. 2005, 249, 1776-1796.

4. Kato, R. Conductive copper salts of 2,5-disubstituted $N, N^{\prime}$-dicyanobenzoquinonediimines (DCNQIs): structural and physical properties. Bull. Chem. Soc. Jpn. 2000, 73, 515-534.

5. Casciola, M. Ionic Conductivity in Layered Materials. In Comprehensive Supramolecular Chemistry; Atwood, J.L., Davies, J.E.D., MacNicol, D.D., Vögtle, F., Eds.; Elsevier Science: Oxford, UK, 1996; Volume 7, pp. 355-378.

6. Wu, C.-G.; DeGroot, D.C.; Marcy, H.O.; Schindler, J.L.; Kannewurf, C.R.; Liu, Y.-J.; Hirpo, W.; Kanatzidis, M.G. Redox intercalative polymerization of aniline in $\mathrm{V}_{2} \mathrm{O}_{5}$ xerogel. the postintercalative intralamellar polymer growth in polyaniline/metal oxide nanocomposites is facilitated by molecular oxygen. Chem. Mater. 1996, 8, 1992-2004.

7. Ruiz-Hitzky, E.; Aranda, P.; Darder, M.; Ogawa, M. Hybrid and biohybrid silicate based materials: Molecular vs. block-assembling bottom-up processes. Chem. Soc. Rev. 2011, 40, 801-828.

8. Cao, M.; Djerdj, I.; Jagličić, Z.; Antonietti, M.; Niederberger, M. Layered hybrid organic-inorganic nanobelts exhibiting a field-induced magnetic transition. Phys. Chem. Chem. Phys. 2009, 11, 6166-6172.

9. Song, Y.-F.; McMillan, N.; Long, D.-L.; Thiel, J.; Ding, Y.; Chen, H.; Gadegaard, N.; Cronin, L. Design of hydrophobic polyoxometalate hybrid assemblies beyond surfactant encapsulation. Chem. Eur. J. 2008, 14, 2349-2354.

10. Yan, Y.; Wang, H.; Li, B.; Hou, G.; Yin, Z.; Wu, L.; Yam, V.W.W. Smart self-assemblies based on a surfactant-encapsulated photoresponsive polyoxometalate complex. Angew. Chem. Int. Ed. 2010, 49, 9233-9236.

11. Inumaru, K.; Ishihara, T.; Kamiya, Y.; Okuhara, T.; Yamanaka, S. Water-tolerant, highly active solid acid catalysts composed of the Keggin-type polyoxometalate $\mathrm{H}_{3} \mathrm{PW}_{12} \mathrm{O}_{40}$ immobilized in hydrophobic nanospaces of organomodified mesoporous silica. Angew. Chem. Int. Ed. 2007, 46, 7625-7628.

12. Pope, M.T. Heteropoly and Isopoly Oxometalates; Springer: Berlin, Germany, 1983.

13. Long, D.-L.; Burkholder, E.; Cronin, L. Polyoxometalate clusters, nanostructures and materials: From self assembly to designer materials and devices. Chem. Soc. Rev. 2007, 36, 105-121.

14. Proust, A.; Thouvenot, R.; Gouzerh, P. Functionalization of polyoxometalates: Towards advanced applications in catalysis and materials science. Chem. Commun. 2008, 1837-1852.

15. Okuhara, T.; Mizuno, N.; Misono, M. Catalytic chemistry of heteropoly compounds. Adv. Catal. 1996, 41, 113-252.

16. Sadakane, M.; Steckhan, E. Electrochemical properties of polyoxometalates as electrocatalysts. Chem. Rev. 1998, 98, 219-237. 
17. Huo, Q.; Margolese, D.I.; Ciesla, U.; Demuth, D.G.; Feng, P.; Gier, T.E.; Sieger, P.; Firouzi, A.; Chmelka, B.F.; Schüth, F.; et al. Organization of organic molecules with inorganic molecular species into nanocomposite biphase arrays. Chem. Mater. 1994, 6, 1176-1191.

18. Kanatzidis, M.G. Beyond silica: Nonoxidic mesostructured materials. Adv. Mater. 2007, 19, $1165-1181$.

19. Yamauchi, Y.; Kuroda, K. Rational design of mesoporous metals and related nanomaterials by a soft-template approach. Chem. Asian J. 2008, 3, 664-676.

20. Stein, A.; Fendorf, M.; Jarvie, T.P.; Mueller, K.T.; Benesi, A.J.; Mallouk, T.E. Salt-gel synthesis of porous transition-metal oxides. Chem. Mater. 1995, 7, 304-313.

21. Janauer, G.G.; Dobley, A.; Guo, J.; Zavalij, P.; Whittingham, M.S. Novel tungsten, molybdenum, and vanadium oxides containing surfactant ions. Chem. Mater. 1996, 8, 2096-2101.

22. Taguchi, A.; Abe, T.; Iwamoto, M. Non-silica-based mesostructured materials: Hexagonally mesostructured array of surfactant micelles and 11-tungstophosphoric heteropoly anions. Adv. Mater. 1998, 10, 667-669.

23. Do, J.; Jacobson, A.J. Mesostructured lamellar phases containing six-membered vanadium borophosphate cluster anions. Chem. Mater. 2001, 13, 2436-2440.

24. Polarz, S.; Smarsly, B.; Antonietti, M. Colloidal organization and clusters: self-assembly of polyoxometalate-surfactant complexes towards three-dimensional organized structures. ChemPhysChem 2001, 457-461.

25. Zhang, G.; Ke, H.; He, T.; Xiao, D.; Chen, Z.; Yang, W.; Yao, J. Synthesis and characterization of new layered polyoxometallates-1,10-decanediamine intercalative nanocomposites. J. Mater. Res. 2004, 19, 496-500.

26. Janauer, G.G.; Dobley, A.D.; Zavalij, P.Y.; Whittingham, M.S. Evidence for decavanadate clusters in the lamellar surfactant ion phase. Chem. Mater. 1997, 9, 647-649.

27. Spahr, M.E.; Nesper, R. Anhydrous octamolybdate with trimethyl hexadecyl ammoniumu cations. Z. Anorg. Allg. Chem. 2001, 627, 2133-2138.

28. Nyman, M.; Ingersoll, D.; Singh, S.; Bonhomme, F.; Alam, T.M.; Brinker, C.J.; Rodriguez, M.A. Comparative study of inorganic cluster-surfactant arrays. Chem. Mater. 2005, 17, 2885-2895.

29. Nyman, M.; Rodriguez, M.A.; Anderson, T.M.; Ingersoll, D. Two structures toward understanding evolution from surfactant-polyoxometalate lamellae to surfactant-encapsulated polyoxometalates. Cryst. Growth Des. 2009, 9, 3590-3597.

30. Ito, T.; Sawada, K.; Yamase, T. Crystal structure of bis(dimethyldioctadecylammonium) hexamolybdate: A molecular model of Langmuir-Blodgett films. Chem. Lett. 2003, 32, 938-939.

31. Ito, T.; Yamase, T. Inorganic-organic hybrid layered crystal composed of polyoxomolybdate and surfactant with $\pi$ electrons. Chem. Lett. 2009, 38, 370-371.

32. Ito, T.; Mikurube, K.; Abe, Y.; Koroki, T.; Saito, M.; Iijima, J.; Naruke, H.; Ozeki, T. Hybrid inorganic-organic crystals composed of octamolybdate isomers and pyridinium surfactant. Chem. Lett. 2010, 39, 1323-1325.

33. Yamase, T. Photo- and electrochromism of polyoxometalates and related materials. Chem. Rev. 1998, 98, 307-325. 
34. Renneke, R.F.; Pasquali, M.; Hill, C.L. Polyoxometalate systems for the catalytic selective production of nonthermodynamic alkenes from alkanes. Nature of excited-state deactivation processes and control of subsequent thermal processes in polyoxometalate photoredox chemistry. J. Am. Chem. Soc. 1990, 112, 6585-6594.

35. Moriguchi, I.; Orishikida, K.; Tokuyama, Y.; Watabe, H.; Kagawa, S.; Teraoka, Y. Photocatalytic property of a decatungstate-containing bilayer system for the conversion of 2-propanol to acetone. Chem. Mater. 2001, 13, 2430-2435.

36. Hölscher, M.; Englert, U.; Zibrowius, B.; Hölderich, W.F. $\left(\mathrm{H}_{3} \mathrm{~N}\left(\mathrm{CH}_{2}\right)_{6} \mathrm{NH}_{3}\right)_{4}\left[\mathrm{~W}_{18} \mathrm{P}_{2} \mathrm{O}_{62}\right] \cdot 3 \mathrm{H}_{2} \mathrm{O}$, a microporous solid from Dawson anions and 1,6-diaminohexane. Angew. Chem. Int. Ed. 1994, 33, 2491-2493.

37. Gabriel, J.-C.P.; Nagarajan, R.; Natarajan, S.; Cheetham, A.K.; Rao, C.N.R. Hydrothermal synthesis and structure of a mixed valent heteropoly-oxometallate Keggin salt: $\left[\mathrm{PMo}_{4.27} \mathrm{~W}_{7.73} \mathrm{O}_{40}{ }^{6-}\right]\left[\mathrm{H}_{3} \mathrm{~N}\left(\mathrm{CH}_{2}\right)_{6} \mathrm{NH}_{3}{ }^{2+}\right]_{3}$. J. Solid State Chem. 1997, 129, 257-262.

38. Zhang, Z.; Liu, J.; Wang, E.; Qin, C.; Li, Y.; Qi, Y.; Wang, X. Two extended structures constructed from sandwich-type polyoxometalates functionalized by organic amines. Dalton Trans. 2008, 463-468.

39. Paradies, H.H.; Habben, F. Structure of $n$-hexadeeylpyridinium chloride monohydrate. Acta Crystallogr., Sect. C 1993, 49, 744-747.

40. Desiraju, G.R.; Steiner, T. The Weak Hydrogen Bond in Structural Chemistry and Biology; Oxford University Press: New York, NY, USA, 1999.

41. Suezawa, H.; Yoshida, T.; Umezawa, Y.; Tsuboyama, S.; Nishio, M. CH/ $\pi$ interactions implicated in the crystal structure of transition metal compounds - a database study. Eur. J. Inorg. Chem. 2002, 3148-3155.

42. Fuchs, J.; Hartl, H.; Schiller, W.; Gerlach, U. Die kristallstruktur des tributylammoniumdekawolframats $\left[\left(\mathrm{C}_{4} \mathrm{H}_{9}\right)_{3} \mathrm{NH}\right]_{4} \mathrm{~W}_{10} \mathrm{O}_{32}$. Acta Crystallogr. Sect. B 1976, 32, 740-749.

43. Clegg, W.; Harrington, R.W. University of Newcastle, Newcastle Upon Tyne, UK. Private communication, 2005.

44. Long, D.-L.; Kögerler, P.; Parenty, A.D.C.; Fielden, J.; Cronin, L. Discovery of a family of isopolyoxotungstates $\left[\mathrm{H}_{4} \mathrm{~W}_{19} \mathrm{O}_{62}\right]^{6-}$ encapsulating a $\left\{\mathrm{WO}_{6}\right\}$ moiety within a $\left\{\mathrm{W}_{18}\right\}$ Dawson-like cluster cage. Angew. Chem. Int. Ed. 2006, 45, 4798-4803.

45. Slight expansion in the volume of the lattice $(\sim 3 \%)$ was observed at room temperature, which is common for the compounds with long aliphatic chain. See also ref. 32 and references therein.

46. Barsoukov, E.; Macdonald, J.R. Impedance Spectroscopy: Theory, Experiment, and Applications, 2nd Ed.; Wiley-Interscience: Hoboken, NJ, USA, 2005.

47. Eder, D.; Kramer, R. Electric impedance spectroscopy of titania: Influence of gas treatment and of surface area. J. Phys. Chem. B 2004, 108, 14823-14829.

48. Naruke, H.; Kajitani, N.; Konya, T. Insertion-release of guest species and ionic conduction in polyoxometalate solids with a layer-like Anderson structure. J. Solid. State Chem. 2011, 184, 770-777.

49. Fournier, M. Tetrabutylammonium decatungstate(VI). Inorg. Synth. 1990, 27, 81-83. 
50. PROCESS-AUTO; Rigaku Corporation: Tokyo, Japan, 2002.

51. Beurskens, P.T.; Admiraal, G.; Beurskens, G.; Bosman, W.P.; Garcia-Granda, S.; Gould, R.O.; Smits, J.M.M.; Smykalla, C. PATTY; University of Nijmegen: Nijmegen, The Netherlands, 1992.

52. Beurskens, P.T.; Admiraal, G.; Beurskens, G.; Bosman, W.P.; de Gelder, R.; Israel, R.; Smits, J.M.M. DIRDIF99; University of Nijmegen, Nijmegen, The Netherlands, 1999.

53. Sheldrick, G.M. SHELX-97; University of Göttingen: Göttingen, Germany, 1997.

54. CrystalStructure 3.8; Rigaku/MSC: Woodlands, TX, USA, 2006.

55. Pawley, G.S. Unit-cell refinement from powder diffraction scans. J. Appl. Crystallogr. 1981, 14, 357.

(C) 2012 by the authors; licensee MDPI, Basel, Switzerland. This article is an open access article distributed under the terms and conditions of the Creative Commons Attribution license (http://creativecommons.org/licenses/by/3.0/). 